\title{
Effects of Pruning on the Health of Palms
}

\author{
Eric Rosenfeld
}

\begin{abstract}
This literature review gathers the findings of studies of the effects of pruning on palms in an attempt to answer questions about proper maintenance of ornamental specimens. Several species displayed reduction in size of new leaves after pruning. Pruning was found to worsen the health of palms deficient in mobile nutrients, but healthy palms showed only small changes in leaf nutrient composition. Two studies on oil palm (Elaeis guineensis) recorded higher incidence of weather-induced crown fracture, occurring among heavily-pruned specimens. Coconut fruit yield did not change in the first year of experimentation, but significant declines often occurred in subsequent years with continued treatment. Up to ten lowest leaves could be removed from a full-crowned coconut palm without negative effect on fruit yield. Research was lacking on the question of whether leaf pruning leads to reduction of stem diameter in palms. Research tailored more specifically to the concerns of arborists and landscapers working with palms as ornamentals is needed.

Key Words. Coconut; Cocos; Frond; Leaf; Palm; Pruning; Trimming.
\end{abstract}

Pruning of ornamental palms has been a subject of interest and debate among arborists and landscapers, but opinions are often based on individual experience and casual observation rather than experimental data. The purpose of this article is to gather the results of diverse studies on the effects of leaf ("frond") pruning on palms and to present these data in a way that may be useful for professionals in urban forestry and landscaping. For the sake of biological accuracy, palm "fronds" are referred to hereafter as "leaves".

Despite their importance as sense-of-place ornamentals, palms are also a source of concern for property owners in regions where their heavy leaves and fruit are viewed as a liability. In the state of Hawaii, U.S., professional tree climbers are routinely hired to remove developing bunches and inflorescences from coconut palms, as well as a portion of the lower green leaves, at considerable monetary cost to the owner. While cutting off fruit clusters is not considered detrimental - and may actually be beneficial— to palm health, leaf pruning is widely discouraged by horticulturists who theorize that it weakens the plant by reducing its photosynthetic area (Broschat and Meerow 2000; Pfalzgraf 2000). On some properties, coconut palms are trimmed as frequently as three or four times per year, never being given the opportunity to regrow a typical crown. Other species in other states are usually pruned less frequently but more severely, being stripped of all but a few of their topmost leaves. Many tree care professionals claim that heavily-pruned palms exhibit structural weaknesses (shorter, less turgid leaves; reduced crown density; stem tapering) not generally visible on untrimmed or infrequently-trimmed trees in the same vicinities. Some hold that such symptoms are due to other stress factors and not to pruning. Many feel that pruning is acceptable as long as it is done on a limited scale, but opinions vary as to what that means. There is obvious need for solid experimental data to serve as the basis for palm pruning guidelines.

\section{BENEFICIAL EFFECTS}

Some researchers believe that limited pruning of palms could have beneficial effects. Several articles have cited Dolar (1961) as asserting that the 10 to 12 oldest leaves of a mature coconut palm could be removed in order to make nutrients and moisture available to more physiologically-active parts of the tree. In fact, this is not what Dolar stated; he merely cited Sampson (1923), who had written that the 6 to 8 lowest leaves of a coconut palm were past their prime and of little use to the tree.

In areas where drought is a concern, removal of some of the older leaves may help make limited water resources available to younger leaves (Heichel and Turner 1985; Magat et al. 1994). Marar et al. (1970) mentioned that the rate of transpiration was reportedly more rapid in older leaves, but did not cite references. Magat et al. (1994) theorized that loss of water through leaf transpiration could be reduced by $25 \%-50 \%$ if some older green leaves were removed, although recommended at least 18 opened and functional leaves be retained in the crown to maintain productivity. Broschat (1991) showed the complete removal of leaves from Sabal palmetto helped survival after transplantation by reducing evapotranspiration, but he predicted that this would not likely hold true for most other landscape palm species because, unlike S. palmetto, their root tips are capable of regeneration. A later study confirmed this, showing that Phoenix roebelenii fared better when more leaves were retained during and after transplantation under normal watering conditions (Broschat 1994a).

\section{EFFECTS ON SIZE AND PRODUCTION RATE OF NEW LEAVES}

Aldaba (1931) concluded the removal of 7 to 16 of the oldest leaves did not hamper the production of new leaves of coconut palm, Cocos nucifera, but pruning was applied on only one occasion and not maintained. Bailey et al. (1977) recorded significant decline in new leaf production from Cocos nucifera after nine months of treatment at $70 \%$ defoliation. Their method, however, differed considerably from the practices of landscape arborists in that they cut various set percentages of pinnae (leaflets) from all leaves in the crown rather than starting from the bottom of the crown and removing whole leaves. 
Calvez (1976) observed that single-occasion pruning of oil palm, Elaeis guineensis, to retain 17 youngest leaves significantly reduced the length of new leaves produced in the ensuing months. Plants treated thus took two years to fully recover normal leaf size. Tajudin and Yeoh (1987) measured the length, area, and weight of leaves during experimental pruning treatments of oil palm carried out over four years and recorded no changes, except in the third year of the most severe treatment (retaining 24 leaves), in which case new leaves came out significantly shorter in length. Treatment consisted of selectively removing a certain number of leaves from each whorl of the crown.

Mendoza et al. (1987) tried one-time pruning of the forest understory palm Astrocaryum mexicanum at three levels (one-third, two-thirds, and full defoliation) and measured subsequent new leaf production and plant survival. Completelydefoliated juvenile and immature palms produced fewer new leaves than controls. Mature specimens experienced a 30\% increase in leaf production after treatments removing one-third and two-thirds of the oldest leaves. Defoliation was also found to decrease abscission of retained and newly-produced leaves in all age categories except seedlings. Abscission generally decreased proportionately to increased amounts of pruning, especially where older rather than younger leaves were removed.

Oyama and Mendoza (1990) examined the effects of pruning on Chamaedorea tepejilote, an understory palm of neotropical forests. Leaflets were removed at $25 \%, 50 \%$, and $100 \%$ levels on one occasion only. For a 6-month period following treatment, the rate of new leaf production nearly doubled for male palms defoliated at $25 \%$ and $50 \%$ and nearly tripled for those defoliated $100 \%$. Size of new leaves was not measured.

Endress et al. (2004) studied the effects of leaf harvesting on the small forest palm, Chamaedorea radicalis, and found that pruned palms produced leaves at a slightly faster rate but that the leaves were shorter in length. After two years of treatment, new leaves were so much shorter that $48 \%, 54 \%$, and $68 \%$ reductions in overall foliar yield was recorded for treatments consisting of removal of all marketable leaves once, twice, and four times per year, respectively.

Jimenez (2004) found that pruning of pygmy date palm (Phoenix roebelenii) increased production rate but also decreased the length of new leaves. Pruning of all but the five topmost mature leaves was maintained for nine months. Pruned specimens produced an average of 8.3 new leaves per month compared to 5.4 leaves for those left unpruned. Average length of new leaves was $60.9 \mathrm{~cm}$ (24 in) for pruned plants, and $76.7 \mathrm{~cm}$ (30.2 in) for controls. Leaf length averages were reported differently in the abstract than in the data charts.

\section{EFFECTS ON LEAF NUTRIENT COMPOSITION}

Canja et al. (2003) carried out pruning of coconut palm from leaf \#19 (maintaining 18 youngest leaves in the crown) on fertilized specimens over several years and measured changes in foliar nutrient concentrations. Differences between pruned and unpruned palms were insignificant, although percentages of $\mathrm{N}, \mathrm{P}, \mathrm{K}, \mathrm{Cl}, \mathrm{S}$, and $\mathrm{B}$ were slightly higher in pruned palms while percentages of $\mathrm{Ca}, \mathrm{Mg}$, and $\mathrm{Na}$ were slightly lower.

Tajudin and Yeoh (1987) found that leaf nutrient concentrations of $\mathrm{N}$ and $\mathrm{K}$ increased with leaf pruning of oil palm, while $\mathrm{Mg}$ concentrations decreased. They pointed out that the higher $\mathrm{N}$ and $\mathrm{K}$ concentrations in more heavily-pruned palms may have resulted from these elements becoming more readily available due to decreases in fruit bunch production that also resulted from treatments. Pruning methods consisted of selective leaf removal at all levels of the crown.

Palms recycle mobile nutrients such as potassium $(\mathrm{K})$ from old, dying leaves to new, developing ones. In cases where palms are deficient in $\mathrm{K}$ or other mobile nutrients, removal of old leaves has been shown to increase deficiency symptoms and accelerate decline of the plant (Hartley 1988; Broschat 1994b).

\section{EFFECTS ON STRUCTURAL INTEGRITY OF PLANT}

Pfalzgraf (2000) wrote, "Research tells us the following: juvenile leaves are dependent on mature leaves for structural support (Tomlinson 1990)...The individual leaves work well in unison... In removing large portions of mature crown mass, we promote wind failure of juvenile leaves via exposure.” James et al. (2006) demonstrated that the canopy of leaves of the palm Washingtonia robusta provided some damping of the harmonic sway effect that can potentially lead to stem failure in strong winds.

Chan and Duckett (1978) wrote that lower leaves of oil palm gave structural support to the crown through a "bracing effect" in strong winds. They recorded that crown fracture from strong winds only occurred among trees with leaves missing and not among those with a full crown. Calvez (1976) found the highest incidence of weather-induced crown fracture to occur among oil palm specimens with the highest level of pruning.

Many arborists and horticulturists believe that reduction of stem/trunk diameter results from too much pruning of palm leaves (Bailey 2002; Bezona 2004; Gabel 2004). Broschat and Meerow (2000, p. 220) wrote, "Overtrimming reduces the foodmanufacturing efficiency of the living palm and may result in suboptimum caliper development at the point in the crown where diameter increase is currently taking place." Although casual observations of this effect are widely reported, no controlled studies could be found to have formally tested the theory.

\section{EFFECTS ON FRUIT PRODUCTION AND YIELD}

Since pruning reduces the photosynthetic capacity of plants, reduction in fruit yield may be an indication that a palm is being forced to cope with a dwindling supply of carbohydrates by "cutting back" on production. Farmers have been interested in coconut leaf pruning (CLP) for the purposes of increasing light transmission to undercrops and for harvesting of leaves for thatching and other uses. CLP studies have also been carried out to simulate the effects of leaf-feeding insects on fruit yield.

Marar and Padmanabhan (1970) measured the effects of CLP for a period of four years. In one treatment, palms were kept trimmed of their oldest leaves whose accompanying coconut bunches had already been harvested. In the other group, all opened leaves on one side of the tree were removed additionally. No significant change in fruit production was recorded with the first group, but the second group showed a significant decline in average production (45.6 coconuts per year compared to 68.6 before treatment). Another study observed no change in yield after removal of the bottom-most leaves of Cocos nucifera, conducted by Sudhakara et al. (1989), in which 3 to 10 of the oldest leaves were removed during the 5-month dry season of each year over a period of five years.

Bailey et al. (1977) recorded major declines in coconut yield due to increased premature fruit shedding following pruning 
treatments and concluded that defoliation above $40 \%$ has longterm effects on the health of Cocos nucifera. Their method, however, differed from the practices of arborists in that Bailey et al. cut various percentages of pinnae (leaflets) from all leaves in the crown, rather than starting from the bottom of the crown and removing whole leaves.

Magat and colleagues have been carrying out studies on CLP at the Davao Research Center in the Philippines for a number of years. Initially, they pruned palms to retain 23,18 , or 13 youngest leaves out of 31 total, and found no significant decrease in yield after one year of experimentation for all three treatments (Magat and Habana 1991). Later, Magat et al. (1994) tried maintaining CLP for a longer period of time and got different results: Although there was once again no decrease in yield during the first year, trees retaining the 13 youngest leaves showed a $29 \%$ loss in production of nuts in the second year followed by a further $20 \%$ reduction in the third year (a nearly $50 \%$ decline in nut production after three years). Treatments retaining the 18 youngest leaves caused no significant decline and even showed an improved yield in the third year. Thus, it was concluded that maintaining 18 functional leaves in the crown was sufficient to provide optimum yield in Cocos nucifera.

Contrarily, an experiment conducted at the Davao center between 1993 and 2001 recorded a $20 \%$ to $25 \%$ decline in the yield of palms pruned to retain 18 youngest leaves, except where coffee was used as an intercrop. It was suggested that the lack of significant results in the case of coconut + coffee may have been due to coffee's high concentration of nutrients in leaf litter (Secretaria et al. 2003).

The 1991 and 1994 reports by Magat and colleagues are not the only studies to have found Cocos nucifera unresponsive to pruning during the first year of treatment. Aterrado and Abad (1998) pointed out that no changes in yield occurred within the initial year of pruning. After that, palms deprived of $25 \%$ or more of their foliage exhibited decreased fruit set. Eroy et al. (2001) reported that CLP did not significantly affect yield in the first year, but nut yield was reduced by an average of $21 \%$ per tree after two years. The method and amount of pruning were not mentioned.

Extensive research has also been carried out on the effects of pruning on fruit yield in oil palm because older leaves of this species are customarily removed to facilitate the fruit harvesting process. Oil palm is similar to coconut palm in form, although it has more leaves (as many as 64) in the crown (Tajudin and Yeoh 1987; Meerow 1992). Calvez (1976) reported that pruning oil palm to retain the 17 youngest leaves on just one occasion, allowing the crown to recover immediately afterwards, caused significant fruit abortion. A summary of the results of several oil palm studies was provided by Henson (2002). He concluded that fruit yield was maximized under maximum retention of leaves, that pruning of older/lower leaves was less damaging to fruit yield than pruning of younger/higher leaves, that the effects of pruning did not show up until after 8 to 10 months, and that younger specimens recovered from pruning effects more quickly than did older trees.

\section{EFFECTS ON SUSCEPTIBILITY TO PESTS, DISEASE, AND COLD}

It has been suggested that the interweaving of leaf bases surrounding the stem at the crown acts as a buffer in palms to protect the meristem (palm heart) from cool temperatures, so leaf pruning may leave palms more vulnerable to cold (Bailey 2002). Broschat and Meerow (2000 p. 221) wrote, "In the severe 1989 freeze that struck Florida and other areas of the United States, specimens of Sabal palmetto that were over-trimmed in northcentral Florida suffered damage, while those left with a normal canopy and full complement of leaf bases were unscathed."

When palm leaves are lopped off at the petiole base, as is standard practice among arborists, plant tissue become exposed and are said to be highly susceptible to infection from disease, such as Phytophthora, which threatens coconut palm in Hawaii (Uchida et al. 1992). Fusarium oxysporum has spread among ornamental palms in the U.S. partly by means of improperly cleaned pruning saws coming into contact with this sensitive tissue (Pfalzgraf 2002). Calvez (1976) did not find a higher incidence of disease or insect attack in oil palm subjected to pruning treatments, although pruning was applied only once and not maintained.

\section{SUMMARY OF MAJOR POINTS}

* Pruning increased the rate of production of new leaves, but size of new leaves decreased as a result of higher levels of pruning in all experiments in which leaves were measured.

* Nutrient concentrations in retained leaves were not much affected by leaf pruning in healthy palms, but nutrientdeficient palms experienced a worsening of deficiency symptoms when older leaves were removed.

* Studies with oil palm found that heavily-pruned palms were more susceptible to crown fracture under the force of strong winds than those left unpruned.

* Coconut leaf pruning was shown to have significant negative effects on fruit production when fewer than 18 youngest leaves were retained.

* Pruning of younger/higher leaves has shown a stronger negative impact on fruit yield than has pruning of older/ lower leaves for both coconut and oil palm.

* For all studies, there was an 8 to 12 month delay before maintained leaf pruning began to show its effects on fruit yield for coconut palm and oil palm.

* Scientific research is lacking on the question of whether or not leaf pruning causes reduction of trunk diameter (stem tapering) in palms.

* Uncontrolled observation of Sabal palmetto following the 1989 freeze in Florida lends some support to the hypothesis that leaf pruning renders palms more susceptible to cold temperatures.

\section{DISCUSSION}

The information gathered in this literature review lends some support to the hypothesis that routine green leaf pruning structurally weakens and reduces the size of the crown of palm trees over time and compromises their productive capacity, but there is still a need for research tailored to ornamental palms.

Palms that are regularly pruned often exhibit leaves that appear shorter and less turgid than those of unmaintained speci- 
mens, so studies of the effects of pruning on leaf size are of interest. The experimental data summarized above generally show that pruning causes an increase in new leaf production coupled with a decrease in length of new leaves, particularly under more severe pruning treatments. Even though Jimenez (2004) was the only study to apply pruning in a way that compares to practices in the ornamental environment, results were still similar in studies using other pruning methods. It appears that palms try to compensate for lost photosynthetic surface area by producing new leaves more quickly, but fewer carbohydrates are invested or available to make these leaves as large as they would otherwise be. Trials employing methods identical to those currently used on ornamental palms would be useful.

Broschat and Meerow's (2000) explanation of how the removal of green leaves in palms may lead to reduction of stem/ trunk diameter makes logical scientific sense, but experimental data are lacking. Trials must be carried out to show a conclusive link between pruning and stem tapering. Meanwhile, it is clearly observable throughout the island of Oahu, Hawaii that mature coconut palms frequently experience severe stem tapering following transplantation, but this could be due to a number of possible stress factors among which severe leaf pruning is only but one.

Both Calvez (1976) and Chan and Duckett (1978) observed that severe palm pruning weakens the structural integrity of the crown under the force of storm winds and increases the likelihood of crown fracture. Research and modeling show that trees' canopies limit the sway and potential failure of their trunks by counterbalancing and dispersing the forces of wind. Although palms have a small relative canopy size, the leaves still function to dampen sway (Tomlinson 1990; James et al. 2006). Ironically, commercial properties and hotels that keep their palms severely pruned often do so at least in part because they are concerned about leaves breaking off in windy conditions. Anyone can walk around after a night of strong winds in Hawaii and see large sections of green palm leaves lying on the ground which have broken off from a fracture point along the rachis. Trials should be carried out to count the number of green leaves with broken or damaged raches after severe weather for palms pruned at various levels compared to controls. If pruning were found to have a relationship to rachis failure of retained leaves, it could have important implications for public safety and liability concerns.

Many studies have looked at how coconut leaf pruning affects fruit production and yield. Insofar as fruit production and yield can be seen as indicative of overall health, these studies indicate that routine leaf removal is potentially harmful to the plant. Research in the Philippines suggested that it is necessary to retain at least 18 youngest leaves in order to maintain the productivity of coconut palm. Palms in tourist areas and commercial properties in Hawaii and Florida are often not allowed to retain that many leaves. On the other hand, removal of inflorescences and fruit bunches should free up more resources for the plant and may thereby offset the negative consequences of leaf pruning, at least to some extent. Studies that are more specifically addressed to ornamental palms must be undertaken.

Sudhakara et al.'s (1989) results support Sampson's (1923) claim that the bottom 6 to 8 leaves are past their prime and of little value to the coconut palm. Workers servicing coconut palms on a bi-annual or more frequent basis may be able to remove this number of the very lowest green leaves from a full-headed palm and accomplish the goal of preventing leaf senescence before the next trimming cycle without compromising tree health. One complicating factor here is that removal of lower leaves could conceivably result in an accelerated rate of descent and senescence for retained leaves, even though Mendoza et al. (1987) suggests otherwise. Testing this hypothesis would be both simple and worthwhile.

Many palm species are planted in areas close to the edge of their range for cold tolerance. Cocos nucifera is native to the deep tropics, and overnight temperatures during the cool season in both Hawaii and southern Florida can be lower than ideal for the species (Sampson 1923). Considering this, and in light of Broschat and Meerow's (2000) observation of Sabal palmetto after freezing temperatures in Florida, it may be wise to avoid pruning of Cocos and other tropical species between November and March in these states.

Acknowledgments. The author sincerely thanks Hugh Harries (Research Associate, Herbarium, Royal Botanic Gardens, England), Timothy K. Broschat (Professor, University of Florida), Henry Donselman (Palm consultant, California), and Steve Nimz (Consulting arborist, Hawaii) for guidance, assistance, information, and feedback.

\section{LITERATURE CITED}

Aldaba, V.C. 1931. A study of condition of coconut trees in the leafminer infested area. Philippine Journal of Agriculture 2:51-65.

Aterrado, E.D., and R.G. Abad. 1998. Response of coconut to simulated injury levels caused by leaf-feeding pests. Philippine Journal of Crop Science 23(Supplement 1):39.

Bailey, C.C. 2002. Palm pruning: why palms should not be scalped. The Palmateer 9:10-11.

Bailey, P., D. O’Sullivan, and C. Perry. 1977. Effect of artificial defoliation on coconut yields in Papua, New Guinea. Papua, New Guinea Agricultural Journal 28(2, 3, and 4):39-45.

Bezona, N. (2004, June 13). Hurricane season is here-trim those trees. West Hawaii Today. http://www.westhawaiitoday.com/archive/2004/06/13/ LocalNews/233564.html (accessed 8/6/04).

Broschat, T.K. 1991. Effects of leaf removal on survival of transplanted sabal palms. Journal of Arboriculture 17(2):32-33.

Broschat, T.K. 1994a. Effects of leaf removal, leaf tying, and overhead irrigation on transplanted pygmy date palms. Journal of Arboriculture 20(4):210-213.

Broschat, T.K. 1994b. Removing potassium-deficient leaves accelerates rate of decline in Phoenix roebelenii O'brien. HortScience 29(7):823.

Broschat, T.K., and A.W. Meerow. 2000. Ornamental Palm Horticulture. University Press of Florida, Gainsville.

Calvez, C. 1976. Influences on oil palm yield of pruning at different levels. Oleagineux 1(2):57-58.

Canja, L.H., S.S. Magat, and R.Z. Margate. 2003. Long-term coconut leaf pruning (CLP) effects on CBFS: coconut-coffee agroecosystem. C.O.R.D. XIX(2):39-55

Chan, S.K., and J.E. Duckett. 1978. Crown fracture and palm type-initial findings. Planter, Kuala Lumpur 54:142-148. 
Dolar, S.G. 1961. The Environmental Factors and Cultural Practices Affecting Production of Coconut [M.S. Thesis]. Cornell University, Ithaca, New York.

Endress, B.A., D.L. Gorchov, and M.B. Peterson. 2004. Harvest of the palm Chamaedorea radicalis, its effects on leaf production, and implications for sustainable management. Conservation Biology 18(3):822-830.

Eroy, M.N., R.Z. Margate, S.S. Magat, and G.A. Santos. 2001. Development of coconut leaf pruning techniques in bearing palms to increase sunlight transmission and productivity of coconut-based farming systems. Research Highlights 2000. Bureau of Agricultural Research, Department of Agriculture, Diliman, Quezon City, Philippines. $76 \mathrm{pp}$.

Gabel, K. 2004. Preparing coconut palms for the hurricane season. Broward County Extension Education Division. http://broward.ifas. ufl.edu/english/hortcomm/hc020.htm (accessed 7/31/04).

Hartley, C.W.S. 1988. The Oil Palm. Longman Science and Technology, Essex, England.

Heichel, G.H., and N.C. Turner. 1985. Response to defoliation in maple and red oak. Oecologia 57:14-19.

Henson, I.E. 2002. Oil palm pruning and relationships between leaf area and yield: a review of previous experiments. The Planter, Kuala Lumpur 78(916):351-362.

James, K.R., N. Haritos, and P.K. Ades. 2006. Mechanical stability of trees under dynamic loads. American Journal of Botany 93(10): $1522-1530$.

Jimenez, K. 2004. Efecto de la densidad de siembra y la poda en la produccion de hojas comerciales de Phoenix roebelenii (dwarf date palm) en Alajuela, Costa Rica. Revista de Agricultura Tropical 34:53-60.

Magat, S.S., and J.A. Habana. 1991. Effect of leaf pruning levels on the yield of coconut. Philippine Journal of Coconut Studies 16(1):9-11.

Magat, S.S., L.H. Canja, and R.Z. Margate. 1994. Response of coconut to increasing levels of leaf pruning and its implications on farm productivity. Coconut Research and Development Journal 10(2):16-32.

Marar, K.M.M., and V. Padmanabhan. 1970. Studies on the effect of cutting leaves on the yield of coconut palms. Coconut Bulletin $1: 7-11$.
Meerow, A.W. 1992. Betrock's Guide to Landscape Palms. Betrock Information Systems, Cooper City, Florida.

Mendoza, A., D. Pinero, and J. Sarukhan. 1987. Effects of experimental defoliation on growth, reproduction, and survival of Astrocaryum mexicanum. Journal of Ecology 75:545-554.

Oyama, K., and A. Mendoza. 1990. Effects of defoliation on growth, reproduction and survival of a neotropical dioecious palm Chamaedorea tepejilote. Biotropica 22:119-123.

Pfalzgraf, K. 2000. On the pruning of palms. Palms 44(1):47-49.

Pfalzgraf, K. 2002. Loss of a legacy-Fusarium oxysporum and ornamental Phoenix canariensis. Palms 46(4):161-166.

Sampson, H.C. 1923. The Coconut Palm. John Bale Sons and Danielsson Ltd, London.

Secretaria, M.I., S.S. Magat, and L.H. Canja. 2003. Predicting yield of coconut at two leaf pruning levels under four coconut-based crop combinations. The Philippine Agricultural Scientist 86(3):290-302.

Sudhakara, K., K. Kannan, and I.P.S. Nambiar. 1989. Effect of defoliation on the productivity of coconut palm. Journal of Plantation Crops 16 (supplement):457-461

Tajudin, M.H., and K.H. Yeoh. 1987. Effect of leaf removal on fresh fruit bunches production, pp. 227-240. Proceedings of the National Symposium on Oil Palm By-prod for Agro-based Industries, 5-6 November, 1985, organised by Palm Oil Research Institute of Malaysia in collaboration with Universiti Pertanian Malaysia and Forest Research Institute of Malaysia. Publisher: IPMSKM, Bangi, Selangor.

Tomlinson, F.B. 1990. The Structural Biology of Palms. Clarendon Press, New York.

Uchida, J.Y., J.J. Ooka, N.M. Nagata, and C.Y. Kadooka. 1992. A new Phytophthora fruit and heart rot of coconut. Hawaii Institute of Tropical Agriculture and Human Resources, Research Extension Series 138 .

Eric Rosenfeld

ericworking1@gmail.com 
Résumé. Cette littérature fait une revue combinée des recherches et des études concernant les effets de l'élagage sur les palmiers, et ce afin de répondre aux questions à propos de l'entretien adéquat des spécimens ornementaux. Plusieurs espèces ont montré une diminution de la dimension des nouvelles feuilles après l'élagage. On a découvert que l'élagage détériorait la santé des palmiers souffrant de carence en éléments minéraux mobiles tandis que les palmiers en santé montraient seulement de faibles changements sur leur composition en nutriments foliaires. Deux études sur le palmier à huile (Elaeis guineesis) ont enregistré une incidence accrue des fractures de couronne induites par les événements climatiques, et ce parmi les palmiers lourdement élagués. La chute de noix de coco n'avait pas changé lors de la première année de l'expérimentation, mais des déclins significatifs étaient souvent survenus dans les années subséquentes lors d'interventions continues. Jusqu'à 10 des feuilles les plus basses peuvent être enlevées d'un cocotier avec une cime complète, et ce sans effet négatif sur la chute de noix de coco. Les recherches manques à propos de la question à savoir si l'élagage foliaire mène à une réduction du diamètre de la tige du palmier. Une recherche faite surtout en fonction des intérêts des arboriculteurs et des aménagistes qui travaillent avec les palmiers en tant qu'arbres ornementaux est requise.

Zusammenfassung. Diese Literaturübersicht fasst die Ergebnisse von Studien über den Effekt von Rückschnitt von Palmen zusammen, in der Absicht, Fragen zu richtigen Pflegemaßnahmen von ornamentalen Exemplaren zu beantworten. Einige Arten zeigten eine Größenreduktion bei den neuen Blättern nach dem Rückschnitt. Der Rückschnitt verschlechterte auch die Gesundheit von Palmen mit unzureichendem Nährstofftransport. Aber gesunde Palmen zeigten nur geringe Veränderungen in der Blattnährstoffzusammensetzung. Zwei Studien bei Ölpalmen verzeichneten ein größeres Auftreten von windinduziertem Kronenschaden, besonders an stark zurückgeschnittenen Exemplaren. Die Ernte von Kokosnüssen änderte sich nicht im ersten Jahr, aber danach gab es signifikante Einbrüche bei der Ernte in den Folgejahren bei kontinuierlichem Rückschnitt. Bis zu zehn der unteren Blätter konnten aus einer vollkronigen Kokospalme ohne negative Auswirkungen auf den Fruchtertrag entfernt werden. Die Forschung machte keine Angaben zum Einfluss von Rückschnitt auf die Reduktion des Stammdurchmessers. Es besteht Bedarf nach mehr Forschung bei ornamentalen Palmen, die auf die Fragestellung von Arboristen und Landschaftsgärtnern zugeschnitten ist.

Resumen. Esta literatura revisa información reunida de estudios de los efectos de la poda en palmas en un intento de responder a preguntas acerca del mantenimiento apropiado de especímenes ornamentales. Diferentes especies mostraron reducción en tamaño de nuevas hojas después de la poda. Se encontró que la poda agravó la deficiencia en movilidad de nutrientes, pero la salud de las palmas mostró solamente cambios pequeños en la composición de nutrientes de la hoja. Dos estudios en palma de aceite (Elaeis guineensis) registraron alta incidencia de fractura en la copa inducida por el clima, ocurriendo entre especímenes fuertemente podados. El rendimiento de los frutos de cocos no cambió en el primer año de experimentación, pero disminuyó significativamente en los años subsecuentes con tratamiento continuado. No deberían ser removidas más de 10 hojas inferiores de una palma de coco sin efecto negativo en el rendimiento de frutos. La investigación careció de la cuestión de si la poda conduce a la reducción del diámetro de los tallos en las palmas. Se requiere investigación más específica a la preocupación de los arboristas y paisajistas que trabajan con palmas. 